\title{
The Need for Simulated Patient Method Implementation in Pharmaceutical Education in Poland
}

\author{
Magdalena Cerbin-Koczorowska ${ }^{1}$, Piotr Przymuszała ${ }^{1, \star}$, Magdalena Waszyk- Nowaczyk ${ }^{2}$, \\ Beata Plewka², Ryszard Marciniak ${ }^{1}$
}

${ }^{1}$ Department of Medical Education, Poznan University of Medical Sciences, Poznan, POLAND.

2Department of Pharmaceutical Technology, Pharmacy Practice Division, Poznan University of Medical Sciences, Poznan, POLAND.

\begin{abstract}
Background: Changing societal expectations towards pharmacy graduates and increased focus on communication skills, interprofessional collaboration and pharmaceutical care in their curricula, point out necessity of using new educational techniques to introduce pharmacy students to more practical elements of their future profession. Purposes: The aim of presented study was to introduce and discuss the simulated patient method (SP-method) and indicate potential areas of its implementation into pharmacy curriculum, in terms of qualifications of graduates, on the example of Polish legislation. Methodology: PubMed and Google Scholar databases were searched to identify full text English language articles on application of the SP-method in educational scenarios, with particular emphasis on pharmaceutical education. Additionally, the new Ordinance of the Polish Minister of Science and Higher Education, defining educational standards for undergraduate pharmaceutical education, was analysed in search of learning outcomes that could be achieved and verified using the SP-method. Given that the Bloom's cognitive domain can be supported with cheaper educational methods, presented study focused mainly on practical skills. Results: The key findings suggest that the SP-method allows to accomplish many skill-based learning outcomes defined in the undergraduate pharmaceutical curriculum. Potential areas of its implementation include: enhancing communication skills, patient counselling skills, patient education and pharmaceutical care, teamwork and interprofessional collaboration. Conclusion: Pharmacy students, similarly to their colleagues studying medicine or nursing, should be given opportunities to learn using the SP-method.
\end{abstract}

Key words: Simulated patients, Pharmacy students, Pharmaceutical education, Pharmaceutical curriculum, Practical skills.

\section{INTRODUCTION}

Evolution of pharmacists' image and increased societal expectations towards their engagement in patient care are observed in many countries around the world. Process in which pharmacists refocus their attention from drugs (as products) on patients (as beneficiaries) is visible also in Poland. Skowron et al. ${ }^{1}$ in their "Prospects for development of pharmacy in Poland until the year 2030" described a pharmacist as a healthcare provider and a healthcare team member, not only in reference to hospital pharmacies, but also in case of community pharmacies. Changing role of Polish pharmacists' is also noticeable in Medicines Management Policy of Poland for 2018$2022,{ }^{2}$ which points out the necessity to 'strengthen the role of pharmacists in Polish healthcare system'.

Given that education process on medical programs should correspond with needs of the society, ${ }^{3}$ aforementioned situation forces gradual actualization of the pharmacy graduate's profile as well as analysis and adequate modification of pharmacy curriculum. Pharmaceutical studies are still mostly centred on basic sciences, then on drugs and only to a minor extent
Submission Date: 02-03-2020; Revision Date: 08-06-2020; Accepted Date: 23-10-2020

DOI: 10.5530/ijper.54.4.180 Correspondence: Mr. Piotr Przymuszała Chair and Department of Medical Education, Poznan University of Medical

Sciences, 7 Rokietnicka St, 60-806 Poznan, POLAND. Phone no: +48 618452795 Email id: pprzymuszala@ ump.edu.pl

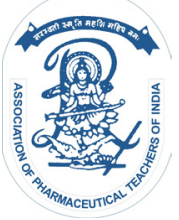

www.ijper.org 
on patients. ${ }^{4}$ However, educational standards for the pharmacy faculty include learning outcomes focused on pharmacist-patient relationship. ${ }^{5}$ Given that contact of pharmacy students with patients described in the educational standards is almost exclusively limited to holiday and work placements (one month after the $3^{\text {rd }}$ year and six months after the $5^{\text {th }}$ year), it seems therefore necessary to provide students with classes that reflect real conditions.

Due to limited access to real patients, simulated conditions are often used to introduce students to practical elements of health practitioner-patient relationship. ${ }^{6}$ They allow students to gain knowledge and skills and practice them multiple times in safe and comforting environment without putting real patients at risk of harm, fatigue or irritation..$^{7-9}$ Many different simulation techniques have been developed over the years, including simple task trainers, mannequins, computer games and virtual patients, role-playing as well as simulated and standardized patients. ${ }^{10}$ The two latter techniques, namely simulated and standardized patients, have become common and valued methods of modern medical education. ${ }^{11}$ They not only allow to provide facts, present procedures and technical skills, but also practice soft skills which are invaluable in terms of contact and communication with patients of healthcare professionals, including future pharmacists. ${ }^{12}$ They also proved to be valuable while measuring students' performance. ${ }^{13,14}$ The aim of this article is to introduce simulated patient methods and discuss possibilities of its implementation into pharmacy curriculum.

\section{SIMULATED AND STANDARDIZED PATIENTS IN EDUCATION}

Unfortunately, there has been a lot of inconsistency on the differences between the two terms and their proper defining., ${ }^{6,7}$ Many authors do not distinguish between them at all, while some others see them as separate terms. ${ }^{6,7}$ Harold Barrows, who is considered a pioneer on the topic, viewed a simulated patient as a normal person carefully trained to portray a real patient, including signs and symptoms. ${ }^{15}$ Contrarily, a standardized patient is considered as a person trained to re-enact a patient scenario or a real patient coached to depict a condition basing on their own history and physical examination. ${ }^{6,7}$ Therefore, the main differences between the terms would revolve around the extent to which 'the patient' plays their role. ${ }^{6,7}$ Simulated patients are supposed to play their roles faithfully according to directions provided by the teacher. They may be considered as actors on a stage and the same scenario can be performed by more than one of them. Standardized patients, on the other hand, do not play a role. They present their own history, symptoms, personality and emotions and have undergone only a brief training to ensure repeatability. Finally, some authors proposed to treat standardized patients as broader concept that covers both real and simulated patients. ${ }^{15,16}$ As a result, there is a strong need to unify the nomenclature as it may be troublesome, especially given their frequent use and growing popularity. ${ }^{6}$

\section{ADVANTAGES AND BARRIERS TO SP-METHOD IMPLEMENTATION}

Many benefits of using simulated and standardized patients have been observed in the literature. As already mentioned, they provide students with an opportunity to safely and stress-free gain, evaluate and ground their knowledge as well as practice their skills in plenitude of scenarios, including but not limited to, anamnesis, physical examination, specific signs or symptoms, initiation of contact, health education and sensitive issues (victims of violence, HIV counselling, healthy sex life or patients with cancer). ${ }^{15,17-19}$ Moreover, as shown by Chen $e t ~ a l .{ }^{20}$ they seem to boost students' confidence and self-esteem and thus increase their comfort when working with real patients. They are highly valued by students and provide depth and context to the learning experience. ${ }^{11,21,22}$ Whenever required, the scene can be started over or paused in order to talk through most vital aspects which would be impossible with real patients. ${ }^{15}$ Furthermore, a trained 'patient' can provide students with meaningful objective feedback and positive reinforcement, additionally reducing their stress prior contact with real patients. ${ }^{8,16,23}$ However, some obstacles have been defined as well, mainly related to its costs and time requirements. ${ }^{16,17}$ Moreover, each re-enactment or scene that 'the patient' is supposed to portray has to be carefully planned, a scenario has to be professionally written and 'patients' trained accordingly. ${ }^{10}$ Last but not least, the method itself has its limitations as not every sign, symptom or disease can be easily portrayed and therefore the recruitment process is difficult. ${ }^{16}$

\section{SP- METHOD FOR PHARMACEUTICAL EDUCATION}

Despite the previously described impact of the SP-method on students' learning, the role of SP is also indisputable in providing high-stake pharmacy examination such as OSCE/OSPE, which are being currently implemented in Poland. ${ }^{23,24}$

Taking into account all the above, the aim of the study was to indicate learning outcomes that could be 
accomplished and assessed with the use of SP-method to ensure the high efficiency of undertaken educational activities.

For the purpose of the study, a literature review was performed using PubMed and Google Scholar databases to identify full text articles published in English concerning application of the SP-method in educational scenarios, with particular attention to pharmaceutical education.
The new Ordinance of the Minister of Science and Higher Education on educational standards for undergraduate pharmaceutical education ${ }^{5}$ also underwent a content analysis in order to select learning outcomes suitable for implementing the SP-method. Although research shows that the use of SP-method improves knowledge retention, ${ }^{25}$ knowledge domain can be supported with cheaper educational methods. In presented study emphasis was put on practical skills.

\section{Table 1: Standards for undergraduate pharmaceutical education possible to accomplish with the use of} SP-method.

\begin{tabular}{|c|c|c|}
\hline Graduate qualifications & $\begin{array}{l}\text { Learning outcomes defined in Polish standards for } \\
\text { undergraduate pharmaceutical education }\end{array}$ & $\begin{array}{l}\text { Literature-based evidences of SP- } \\
\text { method effectiveness }\end{array}$ \\
\hline Basic communication skills & $\begin{array}{l}\text { A.U21. use psychological tools in interpersonal } \\
\text { communication with patients, their caregivers, physicians } \\
\text { and other healthcare system workers. }\end{array}$ & $\begin{array}{l}\text { Austin et al. }{ }^{13} \\
\text { Gillette et al. }{ }^{17} \\
\text { Zhang et al. }{ }^{31} \\
\text { Rickles et al. }{ }^{36} \\
\text { Mafinejad et al. } .^{37}\end{array}$ \\
\hline Patient counselling skills & $\begin{array}{l}\text { C.U33. give information on chemical composition } \\
\text { and therapeutic properties of herbal substances and } \\
\text { preparations; } \\
\text { D.U15. give information on indications and } \\
\text { contraindications to take drugs and their proper dosage } \\
\text { and administration; } \\
\text { D.U30. give advice to patients on interactions of drugs } \\
\text { with food; } \\
\text { D.U31. give information on taking nutritional preparations } \\
\text { and dietary supplements; } \\
\text { E.U2. fill prescriptions (...) and give information on the } \\
\text { drug dispensed; } \\
\text { E.U12. indicate a proper way of conduct with a drug } \\
\text { when a patient is taking it and give information on the } \\
\text { drug; } \\
\text { D.U35. give advice to a patient on taking, } \\
\text { contraindications, interactions and adverse reactions of } \\
\text { drugs of natural origin. }\end{array}$ & $\begin{array}{l}\text { Bowers et al. }{ }^{25} \\
\text { Mafinejad et al. }{ }^{37}\end{array}$ \\
\hline $\begin{array}{l}\text { Patient education and } \\
\text { pharmaceutical care }\end{array}$ & $\begin{array}{l}\text { E.U6. conduct consultations being a part of } \\
\text { pharmaceutical care and pharmaceutical counselling; } \\
\text { E.U14. educate a patient in regards to drugs they take } \\
\text { and other problems concerning their health and disease } \\
\text { (...); } \\
\text { D.U16. give information on drug pharmacology in a way } \\
\text { that is understandable for a patient. }\end{array}$ & Zhang et al. ${ }^{31}$ \\
\hline Delivering bad news & $\begin{array}{l}\text { E.U17. (...) give information on complications of } \\
\text { pharmacotherapy (...) to patients or their families. }\end{array}$ & Kiluk et al..$^{19}$ \\
\hline $\begin{array}{l}\text { Team collaboration } \\
\text { (including interprofessional } \\
\text { collaboration) }\end{array}$ & $\begin{array}{l}\text { D.U17. cooperate with members of other medical } \\
\text { professions in regards to ensuring safety and } \\
\text { effectiveness of pharmacotherapy; } \\
\text { E.U7. collaborate with a physician in regards to } \\
\text { optimization and rationalization of the therapy in inpatient } \\
\text { and outpatient treatment; } \\
\text { E.U23. actively participate in the work of the therapeutic } \\
\text { team, cooperating with healthcare system workers; } \\
\text { A.U19. initiate and support team actions, aid and } \\
\text { remedial, influence formation of attitudes and manage } \\
\text { human resources; } \\
\text { E.U13. indicate a proper way of working with drugs by } \\
\text { workers of the healthcare system. }\end{array}$ & $\begin{array}{l}\text { Shankar et al. }{ }^{11} \\
\text { Zhang et al. }{ }^{31} \\
\text { Westberg et al. }{ }^{38} \\
\text { Koo et al. } .^{39}\end{array}$ \\
\hline
\end{tabular}

Developed on the basis of Ordinance of the Minister of Science and Higher Education on educational standards for undergraduate pharmaceutical education 5 
The majority of identified learning outcomes were linked to pharmacist's ability to communicate with patient and other healthcare professionals (Table 1). Vyas et al. ${ }^{9}$ indicated that the second domain most frequently assessed by simulation at Colleges and Schools of Pharmacy in United States were communication abilities. SP-method is successfully used to teach communication in other parts of the world as well. ${ }^{26}$

Although undergraduate education of healthcare forces in Poland can be described as 'physician-centred', there are some interprofessional learning outcomes listed in different curricula, including pharmacy. ${ }^{27}$ Meanwhile, interprofessional interventions seem to be most effective when they actively engage students to work together, instead of simply learning together without interaction. ${ }^{28}$ Apart from all the aforementioned examples, simulated conditions, including the SP-method, may also be used to realize and verify learning outcomes associated with interprofessional collaboration. For instance, in a study by Panzarella et al. ${ }^{29}$ participation in an IPE program and "seeing firsthand what other professions do" allowed students to better understand professional roles and responsibilities of different members of the medical team and increased their respect for them. Interprofessional SP classes also give students the opportunity to learn new skills by watching other students, improve their communication skills by making them more comfortable talking to other team members and educate them about their own profession. ${ }^{28}$ Additionally, breaks between classes may be also a chance for conversations and getting to know each other in less formal circumstances.

Moreover, some authors demonstrated that simulated patient methods can also be used to teach students technical skills. Bashet ${ }^{30}$ showed that intervention involving pharmacy students educating simulated patients on using one of three asthma inhaler devices, allowed to improve their skills of device technique demonstration. Although mean inhaler technique scores in intervention and control group were not statistically significant, the proportion of students with correct inhaler technique was significantly higher among students who educated simulated patients. Basheti also pointed out that almost every student from the intervention group presented correct technique when they performed it on the exact type used previously to educate simulated patients. Similarly, Bowers et al. ${ }^{25}$ observed that students who gave advice to a simulated patient on proper insulin injection technique not only obtained significantly higher counselling checklist scores, but also their test scores and knowledge retention were significantly higher from the control group. According to Zhang et al. ${ }^{31}$ standardized patients can also be used to practice clinical writing skills and can be useful when presenting rare morbidities to students.

\section{EFFECTIVENESS OF SP- METHOD}

In terms of its effectiveness in comparison with other, less time- and resource-consuming methods (e.g. peer role-play), results of studies conducted so far are mixed, with different studies indicating superiority, equality and one even inferiority of the SP-method. ${ }^{17}$ One of the most widely used methods for training evaluation is the New World Kirkpatrick Model developed by Jim and Wendy Kirkpatrick in 2016, basing on earlier model of Donald Kirkpatrick. ${ }^{32}$ It describes four levels of training evaluation, namely 1 - Reaction, 2 - Learning, 3-Behaviour and 4 - Results. In brief, level 1 denotes participants' reactions to the training (satisfaction, engagement and relevance). Level 2 evaluates knowledge, skills, attitudes, confidence and commitment acquired as a result of the training. Level 3 allows to assess participants' change in behaviour after the training and whether they apply what they learned in practice and Level 4 measures outcomes intended to occur as a result of training.

Previously published studies suggest that learners' satisfaction (Kirkpatrick Level 1) is significantly higher when they work with SP. Flores and Hess ${ }^{33}$ observed that students were more satisfied when drug-induced skin disorders were taught employing a standardized patient dressed in moulage instead of using picture paper cases. This observation is very close to the results of Grice et al. ${ }^{34}$ who compared pharmacy students' satisfaction on teaching physical examination using standardized patients versus manikins. Once again students liked standardized patients better. Neither of above-mentioned studies showed statistically significant differences in students' scores at Kirkpatrick's Level 2.33,34

In another study, however, Gillette et al. ${ }^{17}$ observed improved students' assessment results when they were taught with SP when compared with students taught using peer role-play or other active learning methods. Additionally, in the discussion they pointed out some generalizability issues of previously mentioned papers, including small sample size, short intervention period or assessment of only one aspect of communication. As a result, there is a need for more studies on the topic. Even though, according to most studies, the SP-method may be considered as at least as effective as other methods, it should be mentioned that its cost-effectiveness may differ among institutions due to many reasons, including 
academic teachers' salaries or whether SP receive gratification or not.

\section{CONCLUSION}

Simulation methods, including high-fidelity simulations with simulated patients, are gaining on importance in Poland. Due to financial support of the European Union and the Ministry of Health, twelve academic centres in Poland have recently set up new simulation centres and most of them have already hired or plan to hire actors to play the role of simulated patients. ${ }^{35}$ Unfortunately, among medical programmes that formed the target group of the project, funders did not include future pharmacists. Nevertheless, conducted analysis shows that including simulated patient methods into the education programme at pharmacy faculties would also be justified.

\section{CONFLICT OF INTEREST}

The authors declare no conflict of interest.

\section{ABBREVIATIONS}

SP: Simulated patients.

\section{REFERENCES}

1. Skowron A, Bułaś L, Drozd M, Karolewicz B, Machalska J. Prospects for development of pharmacy in Poland until the year 2030: The document of the national section of pharmaceutical care of the Polish Pharmaceutical Society. Acta Pol Pharm- Drug Res. 2016;73(1):255-66.

2. Ministry of Health. Drug policy of the state 2018-2022 [Polityka lekowa państwa 2018-2022]. Warsaw. 2018.

3. Quintero GA. Medical education and the healthcare system-why does the curriculum need to be reformed?. BMC Med. 2014;12(1):213.

4. Piecuch A, Kozłowska-Wojciechowska M, Jaszewska E, Makarewicz-Wujec M. Farmaceuta kliniczny - odpowiedź na zmieniające się potrzeby społeczne. Farm Pol. 2014;(7):395-9.

5. Ordinance of the Minister of Science and Higher Education on the standards of education preparing for the profession of physician, dentist, pharmacist, nurse, midwife, laboratory diagnostician, physiotherapist and paramedic. [Rozporządzenie Ministra Nauki i Szkolnictwa Wyższego w sprawie standardów kształcenia przygotowującego do wykonywania zawodu lekarza, lekarza dentysty, farmaceuty, pielęgniarki, położnej, diagnosty laboratoryjnego, fizjoterapeuty i ratownika medycznego], Dz. U. 2019 poz. 1573. 2019.

6. Churchouse C, McCafferty C. Standardized Patients Versus Simulated Patients: Is There a Difference?. Clin Simul Nurs. 2012;8(8):e363-5.

7. Beigzadeh A, Bahmanbijari B, Sharifpoor E, Rahimi M. Standardized patients versus simulated patients in medical education: are they the same or different. J Emerg Pract Trauma. 2015;2(1):25-8.

8. Barrows HS. Simulated Patients in Medical Teaching. Canad Med Ass J. 1968;98(14):674-6.

9. Vyas D, Bray BS, Wilson MN. Use of simulation-based teaching methodologies in US colleges and schools of pharmacy. Am J Pharm Educ. 2013;77(3):53.

10. Czekajlo M, Dąbrowski M, Dabbrowska A, Torres K, Torres A. Medical simulation as a professional tool which affect the safety of the patient used in the learning process. [Symulacja medyczna jako profesjonalne narzędzie wpływające na bezpieczeństwo pacjenta wykorzystywane w procesie nauczania]. Pol Med J. 2015;38(228):360-3.

11. Shankar P, Dwivedi NR, Nandy A, Dubey AK. Standardized patient program: Student feedback. Asian J Med Sci. 2016;7(5):102-7.
12. Ainsworth MA, Rogers LP, Markus JF, Dorsey NK, Blackwell TA, Petrusa ER. Standardized Patient Encounters. JAMA. 1991;266(10):1390-6.

13. Austin Z, Gregory P, Tabak D. Instructional design and assessment: Simulated patients vs. standardized patients in objective structured clinical examinations. Am J Pharm Educ. 2006;70(5):1-7.

14. Love DW, Wiese HJ, Henson RE, Parker CL. Teaching interviewing skills to pharmacy residents. Am J Hosp Pharm. 1978;35(9):1073-4.

15. Barrows HS. An overview of the uses of standardized patients for teaching and evaluating clinical skills. Acad Med. 1993;68(6):44-51.

16. Collins P, Harden RMJ. AMEE Medical Education Guide No. 13: Real patients, simulated patients and simulators in clinical examinations. Med Teach. 1998;20(6):508-21.

17. Gillette C, Rudolph M, Rockich-Winston N, Stanton R, Anderson HG. Improving pharmacy student communication outcomes using standardized patients. Am J Pharm Educ. 2017;81(6).

18. Haist SA, Griffith $\mathrm{CH}$, Hoellein AR, Talente G, Montgomery T, Wilson JF. Improving Students' Sexual History Inquiry and HIV Counseling. J Gen Intern Med. 2004;19(5):549-53.

19. Kiluk JV, Dessureault S, Quinn G. Teaching Medical Students How to Break Bad News with Standardized Patients. J Cancer Educ. 2012;27(2):277-80.

20. Chen YC, Kiersma ME, Abdelmageed A. Evaluation of student perceptions of standardized patient simulation on patient counseling confidence during introductory pharmacy practice experiences. Curr Pharm Teach Learn. 2015;7(6):811-8.

21. Pascucci RC, Weinstock PH, O'Connor BE, Fancy KM, Meyer EC. Integrating actors into a simulation program: A primer. Simul Healthc. 2014;9(2):120-6.

22. Robinson JD, Bray BS, Willson MN, Weeks DL. Using human patient simulation to prepare student pharmacists to manage medical emergencies in an ambulatory setting. Am J Pharm Educ. 2011;75(1):3.

23. Smithson J, Bellingan M, Glass B, Mills J. Standardized patients in pharmacy education: An integrative literature review. Curr Pharm Teach Learn. 2015;7(6):851-63.

24. Kowalski T, Skowron A, Nowakowski M. The role and suitability of the objective structured practical examination in pharmacy education in Poland. Indian J Pharm Educ Res. 2019;53(2):186-91.

25. Bowers R, Tunney R, Kelly K, Mills B, Trotta K, Neilwheeless C, et al. Impact of standardized simulated patients on first-year pharmacy students' knowledge retention of insulin injection technique and counseling skills. Am J Pharm Educ. 2017;81(6).

26. Svensberg K, Björnsdottir I, Wallman A, Sporrong SK. Nordic pharmacy schools' experience in communication skills training. Am J Pharm Educ. 2017;81(9):24-35.

27. Cerbin-Koczorowska $M$, Zielińska-Tomczak $Ł$, Waszyk-Nowaczyk $M$, Michalak M, Skowron A. As the twig is bent, so is the tree inclined: A survey of student attitudes toward interprofessional collaboration supported with the curricula analysis. J Interprof Care. 2019;11:1-9

28. Wamsley M, Staves J, Kroon L, Topp K, Hossaini M, Newlin B, et al. The impact of an interprofessional standardized patient exercise on attitudes toward working in interprofessional teams. J Interprof Care. 2012;26(1):28-35.

29. Panzarella K, Rivers L, Bright B, Whelan M, Butterfoss K, Russ L, et al. Using Actors as Simulated Patients for Interprofessional Education. Med Sci Educ. 2013;23(3):438-48.

30. Basheti I. The effect of using simulation for training pharmacy students on correct device technique. Am J Pharm Educ. 2014;78(10):177.

31. Zhang S, Soreide KK, Kelling SE, Bostwick JR. Quality assurance processes for standardized patient programs. Curr Pharm Teach Learn. 2018;10(4):5238.

32. Kirkpatrick J, Kirkpatrick W. Kirkpatrick's four levels of training evaluation. Alexandria (VA), United States: ATD Press. 2016.

33. Flores EK, Hess R. Comparison of Teaching Methods on Skin Disorders: Standardized Patients Dressed with Moulage Versus Paper Cases. Am J Pharm Educ. 2018;82(7):6636.

34. Grice GR, Wenger P, Brooks N, Berry TM. Comparison of patient simulation methods used in a physical assessment course. Am J Pharm Educ. 2013;77(4):77

35. Gąsiorowski Ł, Kuliński D, Stachowiak-Andrysiak M. The Development of Medical Simulation Centers in Poland: A Strong Opportunity for Modernization of Nursing Education. Polish Nurs. 2016;4(62):598-601. 
NM, Tieu P, Myers L, Galal S, Chung V. The impact of a standardized patient program on student learning of communication skills. Am J Pharm Educ. 2009;73(1):4

37. Mafinejad M, Rastegarpanah M, Moosavi F, Shirazi M. Training and validation of standardized patients for assessing communication and counseling skills of pharmacy students: A pilot study. J Res Pharm Pract. 2017;6(2):83.
38. Westberg SM, Adams J, Thiede K, Stratton TP, Bumgardner MA. An interprofessional activity using standardized patients. Am J Pharm Educ. 2006;70(2):34

39. Koo L, Layson-Wolf C, Brandt N, Hammersla M, Idzik S, Rocafort PT, et al. Qualitative evaluation of a standardized patient clinical simulation for nurse practitioner and pharmacy students. Nurse Educ Pract. 2014;14(6):740-6.

\section{PICTORIAL ABSTRACT}

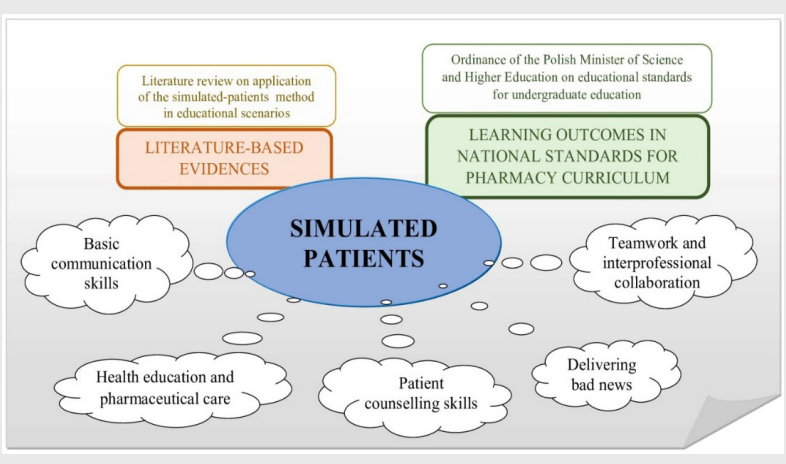

About Authors

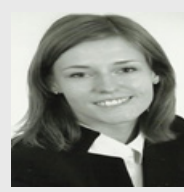

Magdalena Cerbin-Koczorowska, Ph.D, is an Assistant Professor at Chair and Department of Medical Education, Poznan University of Medical Sciences; Fellow of Higher Education Academy, medical educator, distance learning methodologist, medical simulation instructor. Currently studying at the University of Edinburgh at the MSc Clinical Education Programme. She promotes the use of modern educational technologies with particular emphasis on simulation methods in pharmacy.

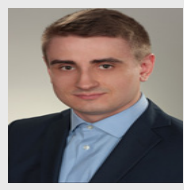

Piotr Przymuszała, MD, is a Ph.D student at Chair and Department of Medical Education, Poznan University of Medical Sciences. His research interests involve medical simulation, simulated patients, communication skills learning, modern educational technologies and students' assessment.

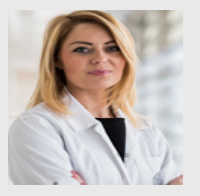

Magdalena Waszyk-Nowaczyk, is an Assistant Professor at Chair and Department of Pharmaceutical Technology, Pharmacy Practice Division, Poznan University of Medical Sciences. She is approved researcher and educator in pharmacy care and patient counselling area. She also practices as a pharmacist in community pharmacies in Poland.

\section{SUMMARY}

- The simulated patient method is gaining importance in Poland. However, its use in the pharmaceutical curriculum is currently limited.

- This study provides a review of the literature on the simulated patient method in educational scenarios. It also indicates potential areas of its implementation into undergraduate pharmaceutical education on the example of learning outcomes listed in the Ordinance of the Polish Minister of Science and Higher Education.

- Results show that the simulated patient method can be implemented to teach and evaluate many skill-based learning outcomes.

- Potential learning outcomes of the undergraduate pharmaceutical curriculum that could be realized with simulated patients include communication skills, patient education, pharmaceutical care, patient counselling skills, giving bad news to the patients and teamwork and interprofessional collaboration.

- Similarly to medical or nursing students, pharmacy students should also have the opportunity to learn with simulated patients.

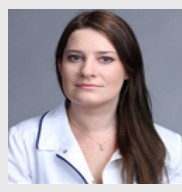

Beata Plewka, is a Ph.D student at Poznan University of Medical Sciences. Her research area focuses on renewal of pharmacy curriculum. In a broader sense, her professional and scientific activity is concentrated on introducing health care services and pharmaceutical care to Polish community pharmacies.

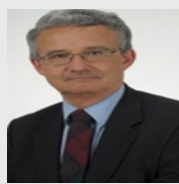

Prof. Ryszard Marciniak, MD, Ph.D, is the Head of Chair and Department of Medical Education, Poznan University of Medical Sciences and surgery specialist. His scientific work is focused on surgery and medical education with emphasis on medical simulation and simulated patients.

Cite this article: Cerbin-Koczorowska M, Przymuszala P, Waszyk- Nowaczyk M, Plewka B, Marciniak R. The Need for Simulated Patient Method Implementation in Pharmaceutical Education in Poland. Indian $\mathrm{J}$ of Pharmaceutical Education and Research. 2020;54(4):875-80. 